\title{
Emisi Gas Rumah Kaca dari Peternakan di Pulau Jawa yang Dihitung dengan Metode Tier-1 IPCC
}

\author{
(Greenhouse Gas Emissions from Livestock in Java Island Calculated by IPCC \\ Tier-1 Method)
}

\author{
Nurhayati IS ${ }^{1}$, Widiawati $\mathrm{Y}^{2}$ \\ ${ }^{1}$ Pusat Penelitian dan Pengembangan Peternakan, Jl. Raya Pajajaran Kav E-59, Bogor 16128 \\ ${ }^{2}$ Balai Penelitian Ternak, PO Box 221, Ciawi, Bogor 16002 \\ imasnurhayati_66@yahoo.co.id
}

\begin{abstract}
Greenhouse gases (GHG) generated from agriculture especially livestock are methane $\left(\mathrm{CH}_{4}\right)$ and Nitrous Oxide $\left(\mathrm{N}_{2} \mathrm{O}\right)$. The GHG emissions from each livestock is different. The GHG emission profile of each region therefore is determined by livestock population. The aim of the study presented in this paper was to determine the GHG emissions from each species of livestock in each province of Java, which was estimated using the IPCC Tier-1 method. In this method the data required is livestock population within one year and emission factor value (EF) of each GHG according to the IPCC manual. The livestock population data was taken from the statistical book, while the EF value was taken from the IPCC book. The results show total GHG emission in Java Island is $30,100,86 \mathrm{Gg} \mathrm{CO}_{2}$-e/year. The beef cattle provide the highest $\mathrm{GHG}$ emissions $(11,684.4$ $\mathrm{GgCO}_{2}$-e/year), while horse is the lowest contributor $\left(104.48 \mathrm{GgCO}_{2}\right.$-e/year). East Java is the highest contributor of GHG emission in Java $\left(11,181.64 \mathrm{GgCO}_{2}\right.$-e/year), while the lowest contributor is DKI Jakarta (18.17 $\mathrm{GgCO}_{2}$-e/year). The $\mathrm{CH}_{4}$ emited from enteric is mostly produced from beef cattle $\left(6,696.22 \mathrm{GgCO}_{2}\right.$-e/year), followed by sheep $\left(1,621.71 \mathrm{GgCO}_{2}\right.$-e/year) and goat $\left(1,119.01 \mathrm{GgCO}_{2}\right.$-e/year). In conclusion, East Java province contributed the highest emission of greenhouse gases (37.15\%), followed by West Java province (30.23\%) and Central Java province (25.18\%). Among all types of livestock, beef cattle is the main contributor $38.49 \%$, followed by sheep $26.90 \%$.
\end{abstract}

Key Words: Emission, Greenhouse Gases, Livestock, Tier-1, Java Island

\begin{abstract}
ABSTRAK
Gas rumah kaca (GRK) yang dihasilkan dari sektor pertanian khususnya peternakan adalah gas metana $\left(\mathrm{CH}_{4}\right)$ dan gas nitrous oxide $\left(\mathrm{N}_{2} \mathrm{O}\right)$. Emisi GRK dari setiap ternak berbeda. Profil emisi GRK dari setiap daerah ditentukan oleh populasi ternaknya. Penulisan makalah ini bertujuan untuk menampilkan gambaran emisi GRK dari setiap jenis ternak di setiap provinsi di Pulau Jawa yang diestimasi dengan menggunakan metode Tier-1 IPCC. Pada metode ini data yang diperlukan adalah populasi ternak dalam satu tahun dan nilai faktor emisi (FE) setiap gas GRK menurut buku panduan IPCC. Data populasi ternak diambil dari buku statistik, sedangkan nilai FE diambil dari buku IPCC. Hasil penghitungan menunjukkan bahwa total emisi GRK di Pulau Jawa sebesar 30.100,86 $\mathrm{CO}_{2}$-e $\mathrm{Gg} /$ tahun. Di Pulau Jawa, sapi potong memberikan emisi GRK tertinggi (11.684,4 $\mathrm{GgCO}_{2}$-e/tahun), sedangkan kuda merupakan penyumbang terendah $\left(104,48 \mathrm{GgCO}_{2-}\right.$ e/tahun). Jawa Timur merupakan provinsi dengan emisi GRK tertinggi di Pulau Jawa (11.181,64 $\mathrm{GgCO}_{2}$-e/tahun) sedangkan DKI Jakarta yang terendah $\left(18,17 \mathrm{GgCO}_{2}\right.$-e/tahun). $\mathrm{Gas} \mathrm{CH}_{4}$ dari enterik yang terbanyak dihasilkan dari sapi potong $\left(6.696,22 \mathrm{GgCO}_{2}\right.$-e/tahun), diikuti domba (1.621,71 $\mathrm{GgCO}_{2}$-e/tahun) dan kambing $\left(1,119,01 \quad \mathrm{GgCO}_{2}\right.$-e/tahun). Kesimpulannya bahwa Provinsi Jawa Timur penyumbang emisi GRK yang terbesar yaitu sebanyak 37,15\%, diikuti oleh Provinsi Jawa Barat sebesar 30,23\% dan Provinsi Jawa Tengah sebanyak 25,18\%. Di antara semua jenis ternak, sapi potong merupakan kontributor utama yaitu sebanyak $38,49 \%$, diikuti oleh domba sebesar $26,90 \%$.
\end{abstract}

Kata Kunci: Emisi, Gas Rumah Kaca, Peternakan, Tier-1, Pulau Jawa 


\section{PENDAHULUAN}

Gas rumah kaca (GRK) merupakan salah satu penyebab meningkatnya suhu bumi yang pada akhirnya menyebabkan terjadinya perubahan iklim. Gas rumah kaca dihasilkan dari semua sektor kehidupan, termasuk di dalamnya dari pertanian. Gas rumah kaca yang dihasilkan dari sektor pertanian khususnya peternakan adalah gas metana $\left(\mathrm{CH}_{4}\right)$ dan gas Nitrous Oxide $\left(\mathrm{N}_{2} \mathrm{O}\right)$. Gas $\mathrm{CH}_{4}$ merupakan tipikal GRK yang diemisikan dari sektor pertanian termasuk peternakan, terutama dari ternak ruminansia. Terdapat dua sumber gas $\mathrm{CH}_{4}$ dari ruminansia, yaitu $\mathrm{CH}_{4}$ yang dihasilkan selama proses pencernaan pakan dalam rumen ternak ruminansia $\left(\mathrm{CH}_{4}\right.$ enterik) dan $\mathrm{CH}_{4}$ yang dihasilkan selama proses dekomposisi kotoran ternak baik ruminansia dan non-ruminansia. Gas $\mathrm{N}_{2} \mathrm{O}$ dihasilkan hanya dari proses dekomposisi kotoran ternak, baik dari ruminansia maupun nonruminansia. Chadwick et al. (2011) menyatakan bahwa limbah peternakan berupa feses yang diolah, feses yang ditumpuk dan feses yang disebarkan di lahan menghasilkan gas rumah kaca. Hal ini berkontribusi terhadap emisi gas rumah kaca secara nasional yang berdampak terhadap pemanasan global.

Gas $\mathrm{CH}_{4}$ mempunyai pengaruh yang lebih besar dibandingkan dengan gas $\mathrm{CO}_{2}$ terhadap pemanasan global, karena daya menangkap panas gas $\mathrm{CH}_{4}$ adalah $25 \times \mathrm{CO} 2$ (Vlaming 2008). Kegiatan pertanian memberikan kontribusi emisi GRK sekitar 5\% dari emisi nasional GRK. Untuk aktivitas produksi ternak diperkirakan memberikan kontribusi sebesar 12\% terhadap total emisi rumah kaca (Dourmad et al. 2008). Widiawati (2013) menyatakan bahwa secara nasional, kontribusi GRK dari sektor peternakan masih relatif rendah yaitu $<1,5 \%$ dari total GRK nasional.

Salah satu subsektor unggulan dalam bidang agribisnis di Pulau Jawa adalah subsektor peternakan. Dengan populasi ternak di Pulau Jawa pada tahun 2015 sebanyak 6.784.413 ekor sapi potong, 519.901 ekor sapi perah, 15.444 .903 ekor domba, 10.657 .171 ekor kambing, 318.841 ekor kerbau, 41.158 ekor kuda, 235.027 ekor babi dan 491.121.335 ekor ternak unggas (BPS 2016). Dilihat dari sisi potensi, usaha peternakan sudah menjadi kebiasaan masyarakat pedesaan di Pulau Jawa sebagai usaha sambilan ataupun sebagai usaha pokok keluarga dan sekaligus dapat dijadikan sebagai sumber pendapatan yang memiliki nilai ekonomi baik bagi pembangunan wilayah maupun bagi petani. Selain itu, pengembangan di subsektor peternakan memberikan kontribusi pada penyerapan jumlah tenaga kerja dan sebagai penghasil sumber pangan protein dalam rangka meningkatkan kualitas sumber daya manusia.

Populasi dan komposisi ternak di setiap propinsi di Pulau Jawa berbeda, yang menghasilkan perbedaan jumlah emisi GRK yang dihasilkan di setiap provinsi. Untuk dapat mengetahui sumbangan emisi GRK dari setiap provinsi di Pulau Jawa, maka dilakukan penghitungan dengan menggunakan metode Tier-1 (IPCC, 2006). Metode Tier-1 ini adalah metode yang paling mudah dan sederhana yang sudah dibakukan di dunia melalui Intergovernment Panel on Climate Change (IPCC), sehingga dapat digunakan oleh semua negara. Pada metode ini data yang diperlukan adalah populasi ternak dalam satu tahun di satu wilayah/negara dan nilai faktor emisi (FE) setiap jenis GRK. Dalam buku panduan IPCC tersebut, telah ditetapkan nilai FE untuk setiap gas dari GRK $\left(\mathrm{CH}_{4}\right.$ dan $\mathrm{N}_{2} \mathrm{O}$ ) dari setiap jenis ternak.

Penulisan makalah ini ditujukan untuk menampilkan gambaran tentang sumbangan emisi GRK dari sektor peternakan di setiap provinsi di Pulau Jawa yang diestimasi dengan menggunakan metode Tier-1 IPCC. 


\section{MATERI DAN METODE}

Emisi GRK dari peternakan dihitung dengan menggunakan metode Tier-1 IPCC. Pada metode ini diperlukan dua data yaitu data populasi ternak dan nilai $\mathrm{FE}$ gas $\mathrm{CH}_{4}$ dan $\mathrm{N}_{2} \mathrm{O}$ dari setiap jenis ternak. Penghitungan dan penggunaan FE untuk setiap jenis ternak perlu dilakukan, karena setiap jenis ternak mengemisikan jenis dan jumlah GRK yang berbeda.

\section{Rumus perhitungan emisi gas rumah kaca melalui metode Tier-1 (IPCC 2006)}

Untuk menghitung emisi gas $\mathrm{CH}_{4}$ yang berasal dari proses fermentasi pakan di dalam rumen (fermentasi enterik) digunakan rumus yang dikeluarkan dalam buku panduan IPCC (2006), yaitu:

Emisi $\mathrm{CH}_{4}$ fermentasi enterik:

Emisi gas $\mathrm{CH}_{4}$ enterik $\left(\mathrm{CO}_{2}\right.$-e ton/ekor $)=$ populasi ternak $($ ekor $) \times \mathrm{FEe}(\mathrm{kg} / \mathrm{ek}) \times 21 / 1000$

Emisi $\mathrm{CH}_{4}$ dari pengelolaan kotoran:

Emisi gas $\mathrm{CH}_{4}$ kotoran $\left(\mathrm{CO}_{2}\right.$-e ton/ekor $)=$ populasi ternak $($ ekor $) \times \mathrm{FEm}(\mathrm{kg} / \mathrm{ek}) \times 21 / 1000$

Emisi $\mathrm{N}_{2} \mathrm{O}$ dari pengelolaan kotoran:

$\mathrm{N}_{2} \mathrm{O}\left(\mathrm{CO}_{2}\right.$-e ton/tahun $)=$ populasi $\times(0,05 \times \mathrm{FEn}) /(1000 / \mathrm{BB}) \times 365 \times 44 / 28 \times 293 / 1000$

\begin{tabular}{|c|c|c|}
\hline \multirow[t]{7}{*}{ Keterangan } & $\mathrm{FEe}$ & Faktor emisi dari enterik ( $\left.\mathrm{kg} \mathrm{CH}_{4} / \mathrm{ekor} / \mathrm{hari}\right)$ \\
\hline & FEm & Faktor emisi dari kotoran ternak ( $\left.\mathrm{kg} \mathrm{CH}_{4} / \mathrm{ekor} / \mathrm{hari}\right)$ \\
\hline & $21 / 1000$ & konversi untuk $\mathrm{CH}_{4}$ ke $\mathrm{CO}_{2}$ dan dari $\mathrm{kg}$ ke ton \\
\hline & FEn & Faktor emisi $\mathrm{N}_{2} \mathrm{O}$ dari kotoran ternak $\left(\mathrm{kg} \mathrm{N}_{2} \mathrm{O} / \mathrm{kg}\right.$ kotoran /hari) \\
\hline & $293 / 1000$ & konversi untuk $\mathrm{N}_{2} \mathrm{O}$ ke $\mathrm{CO} 2$ dan dari kg ke ton \\
\hline & $44 / 28$ & Konversi dari $\mathrm{N}_{2} \mathrm{O}-\mathrm{N}$ menjadi $\mathrm{N}_{2} \mathrm{O}$ \\
\hline & 0,05 & Rataan ekresi N (kg N/ekor/tahun) \\
\hline
\end{tabular}

\section{Data populasi ternak di Pulau Jawa tahun 2015}

Data populasi yang diperlukan dalam penghitungan emisi GRK dengan menggunakan metode Tier-1 adalah populasi dari setiap jenis ternak dalam setahun. Data yang digunakan haruslah merupakan data resmi yang dikeluarkan oleh suatu lembaga pemerintah. Oleh karena itu digunakan data populasi yang dikeluarkan oleh Badan Pusat Statistik nasional. Data populasi untuk setiap jenis ternak disajikan pada Tabel 1.

Tabel 1. Populasi ternak per provinsi di Pulau Jawa pada tahun 2015

\begin{tabular}{lrrrrrrrr}
\hline \hline & \multicolumn{7}{c}{ Populasi (ekor) } \\
\cline { 2 - 9 } Provinsi & Sapi & Sapi & Domba & Kambing & Kerbau & Kuda & Babi & \multicolumn{1}{c}{ Unggas } \\
& Potong & Perah & & & & & & \\
DKI Jakarta & 2.129 & 2.820 & 2.322 & 5.781 & 257 & 107 & - & 22.495 \\
Jawa Barat & 447.999 & 135.345 & 10.826 .494 & 2.395 .881 & 117.313 & 14.891 & 6.895 & 126.805 .557 \\
Jawa Tengah & 1.628 .093 & 123.365 & 2.458 .619 & 3.997 .917 & 67.705 & 13.427 & 139.700 & 82.465 .311 \\
DIY & 322.775 & 4.504 & 176.005 & 411.209 & 1.015 & 2.030 & 13.743 & 9.499 .122 \\
Jawa Timur & 4.326 .261 & 253.830 & 1.242 .526 & 3.136 .513 & 28.520 & 10.536 & 41.882 & 102.027 .623 \\
Banten & 57.156 & 37 & 738.937 & 709.870 & 104.031 & 167 & 32.807 & 24.619 .613 \\
\hline Total Jawa & 6.784 .413 & 519.901 & 15.444 .903 & 10.657 .171 & 318.841 & 41.158 & 235.027 & 491.121 .335 \\
\hline
\end{tabular}

Sumber: Data Badan Pusat Statistik (2015) 


\section{Faktor emisi (FE) untuk enterik dan pengelolaan kotoran}

Dalam penghitungan emisi GRK dengan menggunakan metode Tier-1, telah ditetapkan oleh IPCC besarnya default faktor untuk FE setiap jenis ternak. Untuk wilayah Indonesia digunakan default faktor FE untuk region Asia. Nilai FE untuk gas $\mathrm{CH}_{4}$ dari enterik dan kotoran ternak disajikan pada Tabel 2. Sedangkan nilai FE untuk gas $\mathrm{N}_{2} \mathrm{O}$ dari kotoran ternak dan bobot badan ternak disajikan pada Tabel 3.

Tabel 2. Faktor emisi (FE) gas $\mathrm{CH}_{4}$ dari fermentasi enterik dan pengeloaan kotoran ternak

\begin{tabular}{lcc}
\hline \hline Ternak & $\begin{array}{c}\text { Proses pencernaan } \\
\text { (kg/ekor/tahun) }\end{array}$ & $\begin{array}{c}\text { Pengelolaan kotoran } \\
\text { (kg/ekor/tahun) }\end{array}$ \\
\hline Sapi potong & 47 & 1,00 \\
Sapi perah & 61 & 31,00 \\
Kerbau & 55 & 2,00 \\
Kambing & 5 & 0,22 \\
Domba & 1 & 0,2 \\
Babi & 18 & 7,00 \\
Kuda & & 2,19 \\
Ayam buras & & 0,02 \\
Ayam ras petelur & & 0,02 \\
Ayam ras pedaging & & 0,02 \\
Itik & & 0,02 \\
\hline
\end{tabular}

Sumber: IPCC (2006)

Tabel 3. Faktor emisi (FE) gas $\mathrm{N}_{2} \mathrm{O}$ dari pengelolaan kotoran ternak

\begin{tabular}{lccc}
\hline \hline Jenis ternak & $\begin{array}{c}\text { Faktor emisi } \\
\mathrm{kg} \mathrm{N} \text { O/ekor/hari }\end{array}$ & $\begin{array}{c}\text { Bobot badan } \\
(\mathrm{kg})\end{array}$ & $\begin{array}{c}\text { Lama pemeliharaan } \\
\text { (hari) }\end{array}$ \\
\hline Sapi potong & 0,34 & 250,0 & 365 \\
Sapi perah & 0,47 & 300,0 & 365 \\
Domba & 1,17 & 45,0 & 365 \\
Kambing & 1,37 & 45,0 & 365 \\
Kerbau & 0,32 & 300,0 & 365 \\
Kuda & 0,46 & 550,0 & 365 \\
Babi & 0,82 & 24,5 & 365 \\
Unggas & 0,05 & 1,5 & 365 \\
\hline
\end{tabular}

Sumber: IPCC (2006)

Penghitungan emisi GRK dari sektor peternakan yang dilakukan dengan menggunakan metode Tier-1 IPCC disajikan dalam 3 bagian, yaitu emisi gas $\mathrm{CH}_{4}$ dari fermentasi enterik, emisi gas $\mathrm{CH}_{4}$ dari kotoran ternak, emisi gas $\mathrm{N}_{2} \mathrm{O}$ dari kotoran ternak. Dari ketiga penghitungan tersebut kemudian dapat diketahui total emisi GRK yang dikeluarkan dari sektor peternakan. 


\section{HASIL DAN PEMBAHASAN}

Nilai emisi GRK yang dihasilkan sektor peternakan di setiap provinsi di Pulau Jawa pada tahun 2015 ditunjukkan pada Tabel 4.

Tabel 4. Emisi GRK dari semua jenis ternak di setiap provinsi di Pulau Jawa

\begin{tabular}{|c|c|c|c|c|c|c|c|c|}
\hline Provinsi & $\begin{array}{c}\text { Sapi } \\
\text { Potong }\end{array}$ & $\begin{array}{c}\text { Sapi } \\
\text { Perah } \\
\end{array}$ & Domba & Kambing & Kerbau & Kuda & Babi & Unggas \\
\hline \multicolumn{9}{|c|}{ Emisi fermentasi enterik ( $\left.\mathrm{CO}_{2}-\mathrm{e} \mathrm{Gg} / \mathrm{tahun}\right)$} \\
\hline DKI Jakarta & 2,10 & 3,61 & 0,24 & 0,61 & 0,30 & 0,04 & 0,00 & 0,00 \\
\hline Jawa Barat & 442,18 & 173,38 & 1136,78 & 251,57 & 135,50 & 5,63 & 0,14 & 0,00 \\
\hline Jawa Tengah & 1606,93 & 158,03 & 258,15 & 419,78 & 78,20 & 5,08 & 2,93 & 0,00 \\
\hline DI Yogyakarta & 318,58 & 5,77 & 18,48 & 43,18 & 1,17 & 0,77 & 0,29 & 0,00 \\
\hline Jawa Timur & 4270,02 & 325,16 & 130,47 & 329,33 & 32,94 & 3,98 & 0,88 & 0,00 \\
\hline Banten & 56,41 & 0,05 & 77,59 & 74,54 & 120,16 & 0,06 & 0,69 & 0,00 \\
\hline Total Jawa & 6696,22 & 666,00 & 1621,71 & 1119,01 & 368,26 & 15,56 & 4,94 & 0,00 \\
\hline \multicolumn{9}{|c|}{$\mathrm{CH}_{4}$ manure $\left(\mathrm{CO}_{2}-\mathrm{e} \mathrm{Gg} /\right.$ tahun $)$} \\
\hline DKI Jakarta & 0,04 & 1,84 & 0,01 & 0,02 & 0,01 & 0,00 & 0,00 & 0,01 \\
\hline Jawa Barat & 9,41 & 88,11 & 34,10 & 8,55 & 4,93 & 0,52 & 1,01 & 79,89 \\
\hline Jawa Tengah & 34,19 & 80,31 & 7,74 & 14,27 & 2,84 & 0,47 & 20,54 & 51,95 \\
\hline DI Yogyakarta & 6,78 & 2,93 & 0,55 & 1,47 & 0,04 & 0,07 & 2,02 & 5,98 \\
\hline Jawa Timur & 90,85 & 165,24 & 3,91 & 11,20 & 1,20 & 0,37 & 6,16 & 64,28 \\
\hline Banten & 1,20 & 0,02 & 2,33 & 2,53 & 4,37 & 0,01 & 4,82 & 15,51 \\
\hline Total Jawa & 142,47 & 338,45 & 48,64 & 38,04 & 13,39 & 1,43 & 34,55 & 217,63 \\
\hline \multicolumn{9}{|c|}{$\mathrm{N}_{2} \mathrm{O}$ manure $\left(\mathrm{CO}_{2}\right.$-e $\mathrm{Gg} /$ tahun $)$} \\
\hline DKI Jakarta & 1,52 & 3,34 & 1,03 & 2,99 & 0,21 & 0,23 & 0,00 & 0,01 \\
\hline Jawa Barat & 319,98 & 160,36 & 4789,73 & 1241,15 & 94,63 & 31,66 & 11,64 & 79,91 \\
\hline Jawa Tengah & 1162,85 & 146,16 & 1087,71 & 2071,06 & 54,62 & 28,54 & 235,83 & 51,97 \\
\hline DI Yogyakarta & 230,54 & 5,34 & 77,87 & 213,02 & 0,82 & 4,32 & 23,20 & 5,99 \\
\hline Jawa Timur & 3089,99 & 300,74 & 549,70 & 1624,82 & 23,01 & 22,40 & 70,70 & 64,30 \\
\hline Banten & 40,82 & 0,04 & 326,91 & 367,74 & 83,92 & 0,36 & 55,38 & 15,52 \\
\hline Total Jawa & 4845,70 & 615,98 & 6832,96 & 5520,78 & 257,20 & 87,50 & 396,76 & 217,70 \\
\hline \multicolumn{9}{|c|}{ Total emisi $\left(\mathrm{CO}_{2}\right.$-e $\mathrm{Gg} /$ tahun $)$} \\
\hline DKI Jakarta & 3,67 & 8,79 & 1,28 & 3,62 & 0,51 & 0,27 & 0,00 & 0,03 \\
\hline Jawa Barat & 771,56 & 421,84 & 5960,62 & 1501,27 & 235,06 & 37,80 & 12,80 & 159,80 \\
\hline Jawa Tengah & 2803,97 & 384,50 & 1353,61 & 2505,11 & 135,66 & 34,09 & 259,30 & 103,92 \\
\hline DI Yogyakarta & 555,90 & 14,04 & 96,90 & 257,67 & 2,03 & 5,15 & 25,51 & 11,97 \\
\hline Jawa Timur & 7450,86 & 791,14 & 684,08 & 1965,35 & 57,14 & 26,75 & 77,74 & 128,58 \\
\hline Banten & 98,44 & 0,12 & 406,83 & 444,81 & 208,44 & 0,42 & 60,89 & 31,03 \\
\hline Total Jawa & 11684,4 & 1620,43 & 8503,32 & 6677,83 & 638,84 & 104,48 & 436,24 & 435,33 \\
\hline
\end{tabular}


Dari hasil penghitungan, diketahui bahwa provinsi Jawa Timur menyumbang emisi gas $\mathrm{CH}_{4}$ yang dihasilkan melalui proses fermentasi enterik tertinggi yaitu 48,54\% dari emisi $\mathrm{CH}_{4}$ total di Pulau Jawa; diikuti oleh Jawa Tengah 24,11\%; Jawa Barat 20,46\%; Yogyakarta dan Banten masing-masing 3,70\% dan 3,14\%, serta DKI Jakarta <1\%. Hal ini sejalan dengan populasi ternak ruminansia di setiap provinsi di Pulau Jawa. Populasi ternak ruminansia di DKI Jakarta hanya 33.416 ekor, merupakan provinsi dengan populasi ternak ruminansia terkecil di antara provinsi lainnya di Pulau Jawa. Jawa Timur dengan populasi ternak ruminansia sebesar 8.998 .186 ekor atau sekitar $26,64 \%$ dari total populasi ternak ruminansia di Pulau Jawa merupakan penyumbang GRK terbesar di Pulau Jawa.

Sumbangan emisi $\mathrm{CH}_{4}$ dari sapi potong merupakan yang terbesar $(63,8 \%)$ dari total emisi $\mathrm{CH}_{4}$ dari enterik di Pulau Jawa, dimana provinsi Jawa Timur penyumbang terbesar yaitu sekitar $63,76 \%$ atau sebesar $4.270 \mathrm{CO}_{2}$-e $\mathrm{Gg}$ /tahun. Hal ini sejalan dengan populasi sapi potong yang paling banyak di Pulau Jawa yaitu 4.326.261 ekor. Sapi potong di Jawa Tengah dengan populasi sebanyak 1.628 .093 ekor menghasilkan emisi gas $\mathrm{CH}_{4}$ enterik tertinggi kedua setelah Jawa Timur yaitu $1.607 \mathrm{CO}_{2}$-e $\mathrm{Gg} /$ tahun atau sekitar $24 \%$ dari total emisi $\mathrm{CH}_{4}$ enterik dari sapi potong di Pulau Jawa.

Emisi gas $\mathrm{CH}_{4}$ enterik disumbang dari sapi perah di Provinsi Jawa Timur sejalan dengan populasi sapi perah yang terbanyak berada di provinsi ini, yaitu sebesar $48,82 \%$ dari total populasi sapi perah di Pulau Jawa. Emisi $\mathrm{CH}_{4}$ enterik yang dikeluarkan oleh domba terbanyak di provinsi Jawa Barat dimana populasi domba merupakan 70,10\% dari total populasi domba di Pulau Jawa. Emisi gas $\mathrm{CH}_{4}$ enterik dari kambing didominasi oleh provinsi Jawa Tengah dan Jawa Timur, karena kedua provinsi ini merupakan sentra kambing di Pulau Jawa.

Pada umumnya emisi gas $\mathrm{CH}_{4}$ enterik dari ternak ruminansia di Provinsi Banten dan DKI Jakarta relatif rendah karena populasi ternak ruminansia di kedua provinsi tersebut relatif rendah. Terkecuali untuk ternak kerbau, di provinsi Banten dan Jawa Barat kerbau memberikan emisi gas $\mathrm{CH}_{4}$ yang terbesar diantara provinsi lainnya.

Berdasarkan hasil di atas dapat dilihat bahwa besarnya sumbangan emisi gas $\mathrm{CH}_{4}$ dari enterik di setiap provinsi sangat dipengaruhi oleh populasi sapi potong. Jawa Barat dengan populasi domba yang sangat besar (10.826.494 ekor), namun hanya menyumbang emisi $\mathrm{CH}_{4}$ enterik sebesar $20,45 \%$ dari total $\mathrm{CH}_{4}$ enterik di Pulau Jawa. Namun provinsi Jawa Timur dengan populasi sapi potong sebanyak 4.326.261 ekor menyumbang emisi $\mathrm{CH}_{4}$ enterik terbesar, yaitu sebanyak 48,54\% dari total emisi $\mathrm{CH}_{4}$ enterik di Pulau Jawa. Hal ini sejalan dengan apa yang dilaporkan oleh Shibata \& Terada (2010), bahwa diantara semua ternak, ruminansia merupakan penyumbang $\mathrm{CH}_{4}$ yang utama. Hal ini disebabkan ruminansia mempunyai lambung depan yaitu rumen yang sangat besar dimana berlangsung proses fermentasi yang terus menerus. Rumen merupakan $70 \%$ bagian dari total kapasitas saluran pencernaan pada ruminansia. Sapi potong juga merupakan penyumbang terbesar, karena disamping populasinya yang terbanyak diantara sapi perah dan kerbau, juga dikarenakan volume rumen yang lebih besar yaitu sekitar 100-150 liter dibandingkan volume domba /kambing yang hanya 15 liter.

Emisi gas $\mathrm{CH}_{4}$ dari kotoran ternak memberikan gambaran yang berbeda dengan emisi $\mathrm{CH}_{4}$ enterik. Ternak unggas memberikan kontribusi $\mathrm{CH}_{4}$ dari kotoran yang cukup besar jika dibandingkan dengan kontribusinya pada emisi $\mathrm{CH}_{4}$ enterik. Kontribusi emisi gas $\mathrm{CH}_{4}$ dari pengelolaan kotoran ternak di Pulau Jawa sebagian besar dihasilkan dari kotoran sapi perah terutama di Jawa Timur, Jawa Barat dan Jawa Tengah dimana sejalan dengan jumlah populasi sapi perah di ketiga provinsi ini. Emisi gas $\mathrm{CH}_{4}$ dari pengelolaan kotoran dihasilkan pula dari pengelolaan kotoran ternak sapi potong yaitu tertinggi di Jawa Timur diikuti Jawa Tengah. Berdasarkan hasil pengamatan Merino et al. (2011) bahwa emisi $\mathrm{CH}_{4}$ dari kotoran sapi potong hanya $6,02 \%$ nya dari $\mathrm{CH}_{4}$ yang dihasilkan dari kotoran sapi 
perah. Demikian juga kambing dan domba hanya menghasilkan $\mathrm{CH}_{4}$ dari kotoran sebesar 0,91\% dari $\mathrm{CH}_{4}$ yang dihasilkan oleh kotoran sapi perah. Hal ini mengindikasikan bahwa sapi perah merupakan penyumbang $\mathrm{CH}_{4}$ dari pengelolaan kotoran yang terbesar diantara ternak ruminansia lainnya.

Nilai emisi dari pengelolaan kotoran unggas juga memiliki nilai emisi yang cukup tinggi terutama di Jawa Barat, Jawa Timur dan Jawa Tengah sejalan dengan populasi unggas di ketiga provinsi ini. Seperti dilaporkan oleh Zhou et al. (2007) bahwa di Cina, pengelolaan kotoran dari monogastrik memberikan kontribusi GHG yang signifikan pada emisi GRK dibandingkan dari fermentasi enterik. Selanjutnya disampaikan pula oleh Ji \& Park (2012) bahwa ternak monogastrik merupakan penyumbang GRK dari pengelolaan kotorannya.

Prayitno et al. (2014) menyatakan bahwa emisi $\mathrm{CH}_{4}$ dari pengelolaan kotoran salah satunya dipengaruhi oleh jenis pakan yang diberikan. Umumnya kotoran ternak yang mengkonsumsi pakan berserat akan menghasilkan $\mathrm{CH}_{4}$ lebih tinggi dibandingkan dengan kotoran ternak yang mengkonsumsi pakan asal biji-bijian. Dengan demikian meskipun populasi sapi potong lebih tinggi dari sapi perah, namun emisi $\mathrm{CH}_{4}$ dari pengelolaan kotoran sapi perah cenderung menghasilkan emisi $\mathrm{CH}_{4}$ yang lebih tinggi dibandingkan dengan emisi $\mathrm{CH}_{4}$ yang dihasilkan sapi potong karena pakan yang diberikan pada sapi potong terutama pada usaha penggemukan lebih banyak mengandung konsentrat dibandingkan dengan jumlah pakan yang berserat. Jenis pakan yang bernutrisi tinggi cenderung menghasilkan produksi metana dalam jumlah yang rendah (Bamualim et al. 2008) seperti pakan konsentrat sedangkan pakan hijauan menyumbangkan emisi gas rumah kaca yang lebih tinggi terutama pakan hijauan yang tinggi serat kasar. Gas $\mathrm{CH}_{4}$ pada limbah ternak dihasilkan dari proses dekomposisi bahan organik yang terkandung pada limbah melalui proses fermentasi (IPCC 2006). Di Indonesia umumnya peternak sapi perah menyimpan kotoran sapi perahnya dalam bentuk basah karena bercampur dengan air pencucian kandang. Hal ini menyebabkan jumlah emisi gas $\mathrm{CH}_{4}$ dari kotoran sapi perah menjadi lebih besar jika dibandingkan dengan sapi potong. Umumnya sistem penyimpanan kotoran sapi potong lebih kering dibandingkan sapi perah, yang menyebabkan rendahnya emisi gas $\mathrm{CH}_{4}$.

Hasil perhitungan emisi gas $\mathrm{N}_{2} \mathrm{O}$ dari kotoran ternak dengan menggunakan metode Tier-1 menunjukkan bahwa nilai emisi $\mathrm{N}_{2} \mathrm{O}$ di Pulau Jawa terbanyak di Jawa Barat yang dihasilkan dari pengelolan kotoran domba. Emisi $\mathrm{N}_{2} \mathrm{O}$ tertinggi kedua adalah dari Jawa Timur dihasilkan dari pengelolaan kotoran sapi potong. Sedangkan emisi $\mathrm{N}_{2} \mathrm{O}$ tertinggi ketiga dari Jawa Tengah dihasilkan dari pengelolaan kotoran kambing. Hasil ini menunjukkan adanya perbedaan sumbangan GRK dari setiap provinsi di Pulau Jawa, dan sangat tergantung kepada komposisi dan populasi ternak yang ada.

Emisi GRK yang dihasilkan dari sektor peternakan merupakan penjumlahan dari emisi gas $\mathrm{CH}_{4}$ baik dari proses fermentasi enterik maupun emisi gas $\mathrm{CH}_{4}$ dari pengelolaan kotoran dan gas $\mathrm{N}_{2} \mathrm{O}$ yang dihasilkan dari pengelolaan kotoran. Jumlah emisi GRK dari ternak sangat dipengaruhi oleh populasi ternak seiring dengan jumlah produksi dan kualitas pakan yang diberikan. Berdasarkan total emisi GRK yang dihasilkan peternakan, dapat dilihat bahwa Jawa Timur, Jawa Tengah dan Jawa Barat mendominasi sumbangan GRK didominasi emisi dari ternak sapi potong, domba dan kambing. Di Provinsi Jawa Timur, sapi potong memberikan sumbangan emisi GRK yang terbesar kemudian diikuti emisi yang dihasilkan ternak kambing. Hal ini diikuti oleh provinsi Jawa Tengah dimana sapi potong memberikan kontribusi terbesar kemudian diikuti pula emisi dari ternak kambing. Lain halnya dengan provinsi Jawa Barat, di mana domba memberikan kontribusi GRK yang paling tinggi, kemudian diikuti oleh kambing dan sapi potong. 
Emisi GRK di Pulau Jawa terbesar disumbang oleh provinsi Jawa Timur (11.181,6 $\mathrm{CO}_{2}$-e $\mathrm{Gg} /$ tahun) dan emisi terbesar berasal dari sapi potong (66,6\%). Penyumbang emisi terbesar kedua selanjutnya adalah Jawa Barat dengan nilai total emisi 9.100,75 $\mathrm{CO}_{2}$-e $\mathrm{Gg} /$ tahun, dengan kontributor terbesar dari domba yaitu sebanyak $65,5 \%$. Untuk emisi terbesar ketiga di Pulau Jawa terdapat di Jawa Tengah dengan nilai total emisi 7.580,17 $\mathrm{CO}_{2}$-e $\mathrm{Gg} /$ tahun dimana sebagian besar berasal dari sapi potong yaitu sebanyak $37 \%$. Provinsi DKI Jakarta merupakan kontributor emisi GRK dari sektor peternakan yang paling rendah yaitu hanya sebesar 18,17 CO2-e Gg/tahun.

\section{KESIMPULAN}

Pulau Jawa memberikan sumbangan emisi GRK sebesar 30.100,86 CO2-e Gg/tahun. Provinsi Jawa Timur merupakan penyumbang emisi terbesar yaitu sebanyak 37,15\%, diikuti oleh provinsi Jawa Barat sebesar 30,23\% dan provinsi Jawa Tengah sebanyak $25,18 \%$. Di antara semua jenis ternak, sapi potong merupakan kontributor utama yaitu sebanyak $38,49 \%$, diikuti oleh domba sebesar $26,90 \%$.

\section{DAFTAR PUSTAKA}

Bamualim AM, Thalib A, Anggraeni YN, Mariyono. 2008. Teknologi peternakan sapi potong berwawasan lingkungan. Wartazoa. 18:149-156.

BPS. 2016. Statistik Peternakan 2015. Jakarta (Indonesia): Badan Pusat Statistik.

Chadwick D, Sommer S, Thorman R, Fangueiro D, Cardenas L, Amon B, Misselbrook T. 2011. Manure management: Implications for greenhouse gas emissions. Anim Feed Sci Technol. 166-167:514-531.

Dourmad JY, Rigolot C, van der Werf H. 2008. Emission of greenhouse gas, developing management and animal farming systems to assist mitigation. In: Livestock and Global Climate Change: British Society of Animal Science. Hammamet, Tunisia, 17-20 May 2008. Cambridge (UK): Cambridge University Press. p. 36-39.

IPCC. 2006. Emission from livestock and manure management. Guidelines for national greenhouse gas inventories. Chapter 10. p. 72-82.

Ji ES, Park KH. 2012. Methane and nitrous oxide emissions from livestock agriculture in 16 local administrative districts of Korea. Asian-Aust. J Anim Sci. 25:1768-1774.

IPCC. 2006. IPCC Guidelines for national greenhouse gas inventories-A primer, Prepared by the national greenhouse gas inventories programme. Eggleston HS, Buendia L, Miwa K, Ngara T, Tanabe K, editors. Hayama (Japan): Institute for Global Environmental Strategies (IGES).

Merino P, Ramirez-Fanlo, E. Arriaga, H. Del Hierro, Artetxe O, Viguria M. 2011. Regional inventory of methane and nitrous oxide emission from ruminant livestock in the Basque Country. J Anifeed. Sci. 166-167:628-640.

Prayitno CH, Fitria R, Samsi M. 2014. Suplementasi heit-chrose pada pakan sapi perah pre-partum ditinjau dari profil darah dan recovery bobot tubuh postpartum. Agripet .14:89-95.

Shibata M, Terada T. 2010 Factors affecting methane production and mitigation in ruminants. J Anim Sci. 81:1-10.

Vlaming JB. 2008. Quantifying Variation in Estimated Methane Emission From Ruminants Using the SF6 Tracer Technique [Thesis]. [Palmerston North (New Zealand)]: Massey University.

Widiawati Y. 2013. Current and future mitigaion activities on methane emission from ruminant in Indonesia. In: Tiesnamurti B, Ginting SP, Las I, Apriastuti D, editors. Data Inventory and 
Mitigation on Carbon Emission and Nitrogen Recycling from Livestock in Indonesia. Jakarta (Indonesia): IAARD Press. p. 33-44.

Zhou JB, Jiang MM, Chen GQ. 2007. Estimation of methane and nitrous oxide emission from livestock and poultry in China during 1949-2003. Energy Policy. 35:3759-3767.

\section{DISKUSI}

\section{Pertanyaan}

1. Metode perhitungan emisi GRK di Pulau Jawa menggunakan Tier-1 IPCC, dengan melibatkan berbagai komoditas ternak. Sedangkan sudah ada metode Tier-2 yang tentunya lebih "up date". Apa kelebihan dari masing-masing metode? Mana yang lebih akurat antara Tier-1 vs Tier-2?

2. Emisi gas metana lebih dipengaruhi pakan, seharusnya penelitian pakan menjadi lebih penting dalam skala kecil dan untuk ternak lokal, kemudian hasilnya dikembangkan secara luas. Pakan yang seperti apa yang dapat menurunkan emisi GRK?

3. Sekarang ini kita tengah meningkatkan populasi sapi agar dapat berswasembada daging, namun dalam makalah saudara menghitung emisi GRK dan apabila ada potensi menurunkan emisi bisa jadi negara Uni Eropa akan memberi bantuan untuk terus menurunkan emisi GRK. Bagaimana dengan tujuan program swasembada daging tersebut?

\section{Jawaban}

1. Perhitungan Tier-2 lebih akurat dari Tier-1, karena memperhitungkan sub kategori umur fisiologis. Hasil perhitungan Tier-2 tidak setinggi Tier-1. Tier-1 dengan faktor emisi hasilnya terlalu tinggi.

2. Pemberian pakan berkualitas dengan serat kasar rendah dapat menurunkan emisi GRK demikian juga pemanfaatan hijauan yang rendah emisi gas metana.

3. Harapan dari penelitian ini rekomendasi mitigasi tidak merupakan kendala untuk mencapai swasembada daging. Emisi gas metana ditekan dengan teknologi mitigasi agar tidak menurunkan produktivitas, tetapi populasi sapi tetap ditingkatkan sehingga menghasilkan efek positif terhadap lingkungan. 